\title{
Several Theoretical Problems about the Traditional Sports Industry of Minority Nationalities in China
}

\author{
Zhihui Jing \\ University of Electronic Science and Technology of China \\ Dept. of Physical Education \\ Chengdu, China \\ E-mail: 1797349031@qq.com
}

\author{
Xiaowei Liu \\ Chengdu Sport University \\ Dept. of Foreign Languages \\ Chengdu, China \\ E-mail:1402155087@qq.com
}

\begin{abstract}
The traditional sports industry of minority nationalities refer to the collection of industries that turn the products and labor service of the traditional sports of minority nationalities into production, exchange, consumption and service so as to develop the culture of the traditional sports of minority nationalities and meet the public's creasing demand for sports. The present traditional sport of minority nationalities is characterized by the following. It is now at its infancy of low level, without the scale of diverse development, the interactive development with its peripheral industry, the integrated planning, or scientific and theoretical basis. It can be divided into material products, information products and labor products of the traditional sport of minority nationalities. Last but not least, the paper puts forward some problems waiting to be researched in the traditional sports industry of minority nationalities.
\end{abstract}

Keywords-traditional sports industry of minority nationalities; characteristics; classification; China

\section{INTRODUCTION}

China is a unified multi-ethnic country. There are 56 nationalities live on 9.6 million square kilometers of land. About 0.10643 billion people of minority takes up 8.41\% of total population of China. During the different progress in history, nation traditional activities are unique and abundant, because the differences in social economy, natural environment, customs, and religions. According to record of "Chinese traditional sports records," There 708 nation traditional sports which have long history, characters, abundant content and various styles, cover the whole China. Such as Mongolian create traditional sports actives like Nomadic Saima, Shuajiao, Shejian which reflect Grassland features. Man, Chaoxian, xibo, Dahaner, Elunchun, Ewenke ethnic groups use natural resources create traditional sports of ethnic characteristics in long life practice such as Qishe, Binxi, Huaxue, Douxiong, Dingshuiguan. Zang ethnic group nature recreation sports in a long history such as traditional Saima, Mashu, Shejian, Shuaijiao, Juzhong, Saipao. Yi, Dong, Buyi, Tujia, Wa, Naxi, Jingpo, Zhuang, Miao ethnic groups create Dengshan, Hualongzhou, Poshuijie, Dumuzhou, Tiaozhugan, Dagouguipo, Datuoluo, ect relying on the special geographical environment. Weiwuer ethnic group create traditional sports activities which reflect national bravery such as wheel swing at a high altitude- "Sahaerdi" and rope walk at a high altitude-“Dawazi" ect. Minority compatriots create a blossoming flower of gorgeous national sport in a long history. It is accompanied with nation development, adapted to production and living, combined with production. It is ethnic wisdom connected with customs, a wonderful work in China's splendid national culture. It shines in the evolution of minority cultures.

After several years of heritage and development, many traditional national sports history buried in China and no longer spread because of some reasons. Parts of the traditional sports are facing the situation of decline or disappear. Development situation is worrying. At the same time, schools also set off a wave of traditional sports and a large number of studies have been started. Study concludes that: As a role of special mode of production of consumption of cultural and spiritual, only go the way of sports industry can make it shine. It is an important subject about how to transform potential resource advantages and factors of production into real economic advantages, give proper statistics and evaluation to industrialization of nation traditional sports, and develop nation traditional sports industry in a vicious circle.

\section{DEFINITION AND CLASSIFICATION OF RELATED CONCEPTIONS OF THE TRADITIONAL SPORTS INDUSTRY}

After reference to and organize related documents and materials we will find out that there exist vague related conceptions both in the fields of nation traditional sports and nation traditional sports industry in the researching filed of current nation traditional sports. This mainly reflected by distinguishes of the nation traditional sports and national sports. If conceptions and contents of these two fields have not been distinguished clearly, the research works will go to a wrong way. Thus the scientificity of the results of the research will be influenced. So it is necessary to define related conceptions in this dissertation.

\section{A. National sports}

National sports is a generic terms of the sports activities held by a nation. It is not restricted to a historical (or traditional) conception, but including traditional sports 
activities and modern sports activities held in eastern regions as well as competitive sports events held in western regions.

\section{B. Nation traditional sports}

Nation traditional sports refers to the generic term of all the activities conducted by certain nations in a certain period in order to contest with living conditions, gain production goods and improve self-mindset and physical health. It mainly includes such nation traditional activities: get rid of illness, body-building, learn material arts, entertainment and religious activities. It possesses four typical characteristics, which are athletic features, national features, traditional features and regional features.

\section{National sports industry}

In regards to the definition of the conception of national sports, national sports industry can be divided into narrow-industry and broad-industry. Narrow national sports industry refers to the operating activities held by a pure ethnic (such as the Miao nationality) to provide related sporting goods and services and gain economic interests. Broad national sports industry, namely the sports industry we generally means, refers to the aggregation of all industries that produce sporting material goods and spiritual goods and provide sports services so as to gain economic interests.

\section{Nation traditional sports industry}

On the basis of referring to related definitions, this research considers that nation traditional sports industry refers to the aggregation of all industries that make nation traditional sporting goods and services can be produced, exchanged, consumer and served in order to develop nation traditional sports culture and meet the increasingly sports demands of people.

\section{DEVELOPMENT CHARACTERISTICS ON OUR NATIONAL TRADITIONAL SPORTS INDUSTRY}

The various enterprises of economy, technology, culture and sports in the territory of nationality are restricted by some factors, such as historical causes, geographic environment and economical development. So the developmental level relatively low and the current situation of developments on traditional sports industry is beyond satisfaction. Consult and take examples by correlation research, and access to some information about investigation and collection. The author thinks that Current situation of developments on our national traditional sports industry is expressed by following sides:

\section{A. Developments on national traditional sports industry are still place in low level of primary budding stage}

Developments on national traditional sports industry are still place in low level of primary budding stage. Just a few national traditional sports events have popularized (like: dragon dance, lion dance, dragon-boat dance, national dance, rock climbing and drifting) and be a commodity and accepted by social. While in the largely rest areas, the national traditional sports events are still in the state of development. So developments on national traditional sports industry are still place in low level of primary budding stage.

\section{B. National traditional sports industrial haven't formed pluralism scales}

Currently, the development of our national traditional sports events develop disequilibrium, unreasonable structure, under-utilization of resource development, insufficient of activity system, sole products content and largely regional gap, which formed "only a few woods can not be a forest. The resource development of our national traditional sports industry mainly plunged by people groups, sports bureau and local government. Social, group, individual and foreign capital has less input. The contents of the development are drifting, rock climbing, skiing, songs and dances and so on. Among the events have not formed equilibrium because of no relations between them.

\section{National traditional sports industry is lack of their interact development with its other industries}

Currently, our national traditional sports industry mainly depends on tour industry. There are some connections between national traditional sports industry and cultural art industry, clothing industry, food industry, but interaction is not enough. Nevertheless, the development of national traditional sports industry has increased as the development of our industry in recent two years. In fact, when national traditional sports industry is combined with other industries, it is not expressed its advantages, just expressed affiliation. Although national traditional sports industry hasn't developed; however, the direct incomes haven't separated from these industries. This is one of the reasons of the slow development.

\section{National traditional sports industry is lack of integrated planning}

National traditional sports industry is lack of integrated planning in many regions and is not formed the system of traditional sports. Therefore, National traditional sports industry is still in a raw natural situation and has a weak awareness of transferring it into economic benefit. So far it haven't formed an independent industry. It is not inconsistent with Special multiple national traditional sports resource in national regions and great natural environment and richness of national amorous feelings.

\section{E. National traditional sports industry is lack of theory systems}

With the various ways of searching theories of national traditional sports industry. So far our country has not formed an independent, theory, scientific national traditional sports industry. Educational circles haven't separated sports industry from national traditional sports industry. Therefore, we must widely research and gradually form relatively theory systems and do some guidance for national traditional sports industry. It can avail for the inheritance and development of traditional 
sports and also avail for the development and use of the resource, then promoting the social and economical development of national regions.

\section{CLASSIFICATIONS OF NATION TRADITIONAL SPORTS INDUSTRY}

In regards to the classifications of nation traditional sports industry, researchers have not achieved an agreement with the verdict. A few scholars agree the idea that all the industries that make nation traditional sporting goods and services can be produced, exchanged, consumed and served in order to meet the increasingly sporting demands of people can be classified into this industry. For example, nation traditional sporting material goods (nation traditional sporting costumes, nation traditional sporting equipments, nation traditional sporting constructions and nation traditional sporting food, etc ), nation traditional sporting information products (nation traditional advertisement, television and broadcasting, newspapers and magazines, etc) and nation traditional sporting services (nation traditional sports competitions, body-building and entertainment and rent of fields, etc).

Besides this categorization, it is hard to find out other categorizations. According to classifications of other industries, the practical development of the nation traditional sports industry in southwestern regions this research categorize the nation traditional sports industry and considers that nation traditional sports industry including three classifications: nation traditional sports preliminary industry, nation traditional sports attached industry, and nation traditional sports management industry. This classification has a wide coverage and coexistence with the division of sports industry, it is more scientific and reasonable to understand .On this ground, in order to elaborate the object of statistics, we engaged in classifying a specific division under the principle of mutual exclusion and exhaustion. Table 1 is as follows:

TABLE 1 STATISTICS' SCOPE AND OBJECT OF NATION TRADITIONAL SPORTS INDUSTRY

\begin{tabular}{|c|c|}
\hline $\begin{array}{l}\text { First class } \\
\text { name }\end{array}$ & Second class name \\
\hline \multirow{4}{*}{$\begin{array}{l}\text { Nation } \\
\text { traditional } \\
\text { sports } \\
\text { preliminary } \\
\text { industry }\end{array}$} & $\begin{array}{l}\text { Nation traditional sports competition and } \\
\text { performance industry }\end{array}$ \\
\hline & $\begin{array}{lccc}\text { Nation traditional sports fitness and } \\
\text { entertainment industry }\end{array}$ \\
\hline & $\begin{array}{l}\text { Nation traditional sports training and consultant } \\
\text { industry }\end{array}$ \\
\hline & $\begin{array}{l}\text { Nation traditional sports assets operation } \\
\text { industry }\end{array}$ \\
\hline \multirow{6}{*}{$\begin{array}{l}\text { Nation } \\
\text { traditional } \\
\text { sports attached } \\
\text { industry }\end{array}$} & $\begin{array}{l}\text { Nation traditional sports } \\
\text { manufacturing industry }\end{array}$ \\
\hline & $\begin{array}{l}\text { Nation traditional sports clothing and souvenir } \\
\text { industry }\end{array}$ \\
\hline & Nation traditional sports architectural industry \\
\hline & Nation traditional sports advertisement industry \\
\hline & $\begin{array}{lccc}\begin{array}{l}\text { Nation traditional } \\
\text { manufacturing industry }\end{array} & \text { sports } & \text { equipment } \\
\end{array}$ \\
\hline & Nation traditional sports consumption industry \\
\hline
\end{tabular}

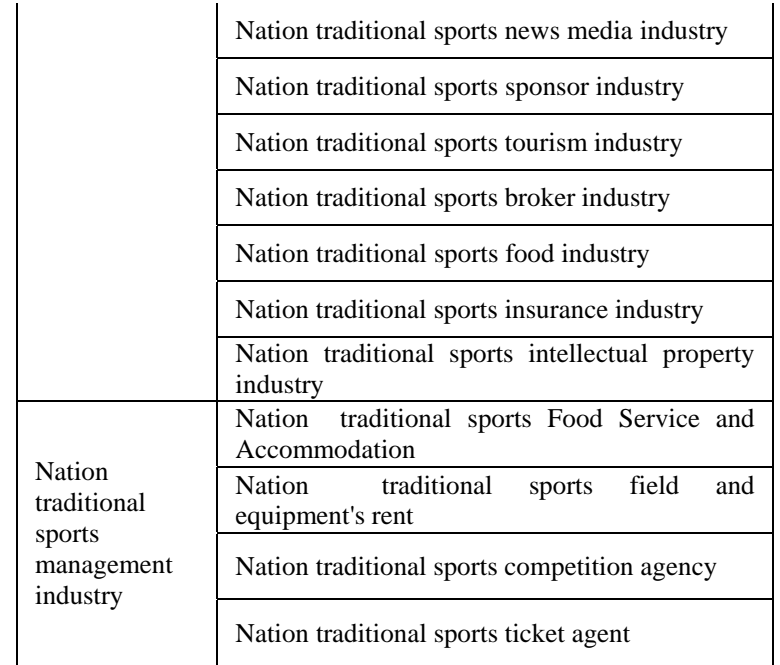

\section{CONCLUSION}

The development of nation traditional sports industry is a necessary phase of the development of nation traditional sports. Only by commercialize and industrialize the nation traditional sporting goods can we promote the development of our nation traditional sports industry and make the glory of our nation traditional sports industry shine. However, stimulus of researches to nation traditional sports is far from enough. Theory is behind the practice. It is in Lack of scientific theory to guide system and a proper system of statistical evaluation. These defects lead it is impossible to give accurate quantitative description of Economic value and industry status of nation traditional sports industry. It influences the knowing of the role of nation traditional sports in stimulating regional economic growth, and constraints of traditional sports culture, industry, communication and investment. On the other hand, it influences recognition and acceptance of nation traditional sports industry in mainstream economists. It makes it meaningless to practice in the field directly related to the theoretical study. In order to adapt to the increasingly developing situation of the nation traditional sports industry and its market, we must build up the indicator system of statistics on nation traditional sports industry and greatly promote statistical works of traditional sports economy and lead the industry to grow up strong and sturdy.

\section{REFERENCES}

During the different progress in history, nation traditional activities are unique and abundant, because the differences in social economy, natural environment, customs, and religions [1]. If conceptions and contents of these two fields have not been distinguished clearly, the research works will go to a wrong way [2]. A few scholars agree the idea that all the industries that make nation traditional sporting goods and services can be produced, exchanged, consumed and served in order to meet the 
increasingly sporting demands of people can be classified into this industry [3].

[1] Huangjian, Discussion of Nation Traditional Industry Development against a Background of Construction of New Rural Economy [J]. Commercial Times, 2010, 9:121-122.
[2] Huangjian, Discussion of Nation Traditional Industry Development against a Background of Construction of New Rural Economy [J]. Commercial Times, 2010, 9:121-122.

[3] Linxianpeng, Research on Establishing System of Statistical Indicators of Sports Industry in China [J] China Sport Science, 2000, 20(4):1-5. 